\title{
Results of tests of devices for sunflower harvesting in economic conditions
}

\author{
Mikhail Chaplygin ${ }^{1, *}$, Olga Bespalova $^{2}$, and Mariya Podzorova ${ }^{1,3}$ \\ ${ }^{1}$ Federal Research Agro-Engineering Center VIM, 1st Institutskiy proezd, 5, Moscow, 109428, Russia \\ ${ }^{2}$ Astrakhan State University,st. Tatishcheva, 20A, Astrakhan, 414056, Russia \\ ${ }^{3}$ Plekhanov Russian University of Economics, 36 Stremyanny per., Moscow, 117997, Russia
}

\begin{abstract}
The results of tests of devices for sunflower harvesting differing in design, the number of rows to be removed, the presence of the chopper stems in real economic conditions and machine testing stations.
\end{abstract}

\section{Introduction}

Sunflower is cleaned with specially equipped devices that can be aggregated with various combine harvesters by means of a special spacer between the device and the inclined chamber of the combine.

Devices for sunflower harvesting are designed for harvesting sunflower seeds and transporting them to the inclined chamber of the combine harvester and consist of a frame, auger, seed conveyors, choppers stems, dividers and cutting units.

According to field studies in economic conditions and reports of machine testing stations (MTS) posted on the sites tested and received a positive conclusion nine samples of devices for harvesting sunflower from different manufacturers presented in table 1 [1,2].

Table 1. General information about the tested devices for sunflower harvesting

\begin{tabular}{|l|l|}
\hline Brand tools & Manufacturer \\
\hline PSP-1210-35 «FALCON» & JSC "Morozovskselmash" of Morozovsk \\
\hline PSP-810-05 «FALCON» & JSC "Morozovskselmash" of Morozovsk \\
\hline NASH-873-04 & Ltd. joint venture "Unisibmash", Novosibirsk \\
\hline OptiSun-870 PSM & OPTIGER Kft, Hungary \\
\hline PSP-810 & JSC "Morozovskselmash" of Morozovsk \\
\hline NASH-873-06 & Ltd. joint venture "Unisibmash", Novosibirsk \\
\hline ZHNS -9,1 & PJSC «Berdyansk header ", Berdyansk \\
\hline PSP-810-13 (2 sample) & JSC "Morozovskselmash" of Morozovsk \\
\hline
\end{tabular}

\footnotetext{
* Corresponding author: zhalnin@yandex.ru
} 


\section{Experimental. Results and discussion}

In the construction of devices for cleaning of sunflower PSP uses the following components: bevel gear cutting machines, lifters, left and right.

Device PSP-810 (Figure 1) is designed for harvesting sunflower seeds in the unit with combine harvesters ACROS, VECTOR, and PSP-810-13 with combine harvesters "ACROS Plus" and "TORUM", equipped with auto.

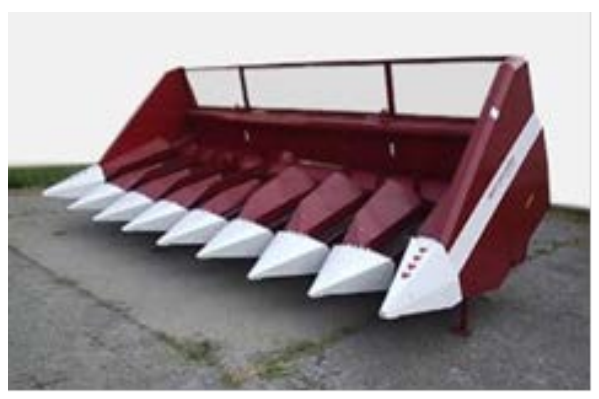

$\mathbf{a}$

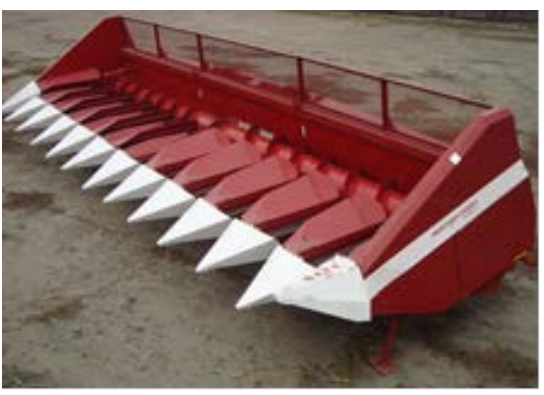

b

Fig. 1. General view of sunflower harvesting devices: model PSP-810-05 «FALCON» (a), model PSP-1210-35 «FALCON» (b).

Bevel gears are designed to drive conveyors of stems and seeds, as well as cutting machines. Drive gearboxes is carried out on both sides of the device cardan shafts. Lifters left and right consist of a divider and a frame on which the driven roller of the belt conveyor of seeds is installed. The divider can take two positions: bottom (working) and top (transport). Each cutting machine consists of a disc with special knives riveted to it and an anti-cutting plate fixed to the glass of the conical reducer. The design of lifters on devices for cleaning sunflower NASH-873-04, NASH-873-06 (Figure 2) allows you to raise or lower the fallen drooping sunflower stalks. For harvesting both low-growing and high-stem sunflower varieties, these devices can change the angle of inclination, and the width of the channel through which the vibrating conveyor of the stems feeds the stems to the cutting machine can be adjusted. This parameter allows the use of devices in all areas of cultivation of sunflower and different varieties. Device for cleaning sunflower OptiSun 870-PSM (Figure 2.b) consists of a frame device, screw conveyors seed grinders stems dividers cutter assemblies.

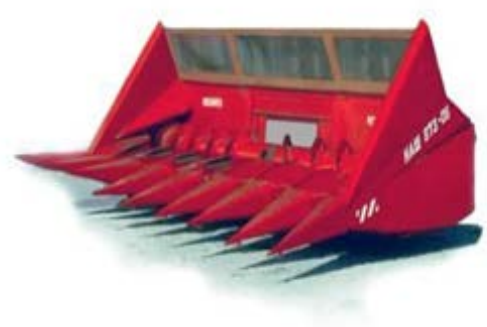

a

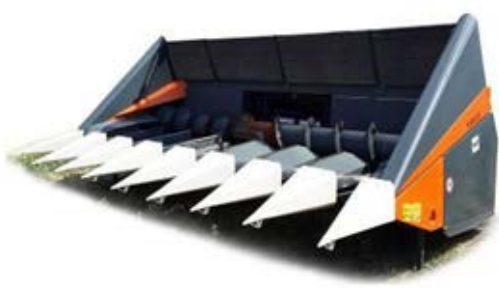

b

Fig. 2. General view of devices for harvesting sunflower models: NASH-873 (a), OptiSun-870-PSM (b). . 
The frame of the device is a welded structure of the gutter shape, which consists of steel styles and steel sheet. The screw is a welded pipe on which the screw tapes of the right and left winding are welded.

The stem shredder consists of four sections, each of which has two rotors. The shredders are driven by a hydraulic system. The hydraulic system consists of a tank with a thermometer, cranes, filter, motion limiter valve, connecting pipes and hydraulic motors. Chopper pumps are two pieces on the left and right side of the device. Each shredder includes one pump and one hydraulic motor. Each hydraulic circuit has a pressure gauge that allows the combine to control the amount of oil pressure. Stem shredders can change their position regardless of the device. Shredders are raised and lowered by means of hydraulics.

Cutting units are designed for supply of the stems of the sunflower and cut baskets. The cutting units consist of two main parts: the first - a spoon chain with a tensioner device and a device for feeding the stems, and the second part - the cutting machine.

Dividers are designed to separate sunflower stems and direct them to the cutting nodes. Frame dividers wedge-shaped execution of sheet steel fixing of the shaped steel.

On the lower part of the tops of the dividers welded plate in the form of a Shoe, which, to some extent, allows you to copy the surface of the field and provides the rise of fallen stems. A stubble height meter is installed on the device, which shows the relative position of the grinder and the device to each other.

Maize Sunflower mounted ZHNS-9,1 consists of a platform and a transition frame hinge. Maize is mounted on an inclined chamber combine any type and grade, by rigid connection by means of the transition frame [3].

Platform harvester consists of a frame welded construction which is provided with the cutting apparatus, the right and left sides, lift attendants, blister, reel, auger, drive mechanisms and safety guards. The right and left sidewalls are designed to separate the sunflower stems from the array and direct them to the header.

Lifters consist of a sock and a gutter and are designed for separation, direction and supply of sunflower stems to the cutting machine, as well as for the collection and passive supply of cut mass to the platform of the header spilled from the baskets of seeds.

The Reaper is driven by a gimbal from the inclined chamber of the combine by a chain drive from the counter-drive shaft to the screw drive shaft and a belt drive to the planetary knife drive reducer. A safety clutch is installed on the screw axle, which is activated when foreign bodies get into the working bodies of the header and prevents their breakage. On the right side drive axle of the reel is chain drive from the axle of the screw.

The cutting machine is assembled on the front bar and consists of steel double fingers of the closed type, a movable knife with segments, clamps, friction plates, slats and adjusting gaskets. Protective shield and protective visors on the top of the platform, prevent the release of cut mass and ensure no loss at the cut stage. Brief technical characteristics of devices for sunflower harvesting are given in tables 2-3.

From the data in table 2 it follows that, despite the same constructive width of the grip, the tested devices have a large spread of the total mass. The smallest total weight is the device PSP-810 $(1770 \mathrm{~kg})$, and the largest OptiSun-870-PSM $(2830 \mathrm{~kg})$. The greatest weight of the device OptiSun-870-PSM is due to the presence of the chopper stems with hydraulic system.

The main difference between the header ZHNS-9.1 devices from PSP-1210-35 «FALCON» (Table 3) that the header ZHNS-9.1 in their designs has lifters that perform two functions: supply of sunflower stems to the cutting machine and collection with passive supply cut weight on the platform header pours out with baskets of seeds. Also, the header design allows you to clean sunflower, both along the rows and diagonally across. 
Table 2. Technical characteristics of devices for harvesting sunflower with the number of rows to be removed eight

\begin{tabular}{|c|c|c|c|c|c|c|}
\hline \multirow{2}{*}{$\begin{array}{l}\text { Name of indicator } \\
\text { Device brand }\end{array}$} & \multicolumn{6}{|c|}{ Value of parameter } \\
\hline & $\begin{array}{l}\text { PSP-810-05 } \\
\text { 《FALCON» }\end{array}$ & $\begin{array}{l}\text { NASH- } \\
873-04\end{array}$ & $\begin{array}{l}\text { OptiSun- } \\
\text { 870-PSM }\end{array}$ & PSP-810 & \begin{tabular}{|l} 
NASH- \\
$873-06$
\end{tabular} & $\begin{array}{l}\text { PSP-810- } \\
13\end{array}$ \\
\hline Structural width, m & 5,6 & 5,6 & 5,6 & 5,6 & 5,6 & 5,6 \\
\hline $\begin{array}{l}\text { Driving speed, } \mathrm{km} / \mathrm{h}: \\
\text { - working } \\
\text { - transport }\end{array}$ & $\begin{array}{l}7,0-10,0 \\
\text { до } 10,0 \\
\end{array}$ & $\begin{array}{l}7,0-10,0 \\
\text { до } 15,0 \\
\end{array}$ & $\begin{array}{l}3,6-4,0 \\
\text { до } 16,0 \\
\end{array}$ & $\begin{array}{l}5,1-5,3 \\
\text { до } 10,0 \\
\end{array}$ & \begin{tabular}{|l|}
$5,0-7,0$ \\
15,0 \\
\end{tabular} & $\begin{array}{l}9,0 \\
\text { до } 20,0\end{array}$ \\
\hline $\begin{array}{l}\text { Overall dimensions, mm: } \\
\text { - length } \\
\text { - width } \\
\text { - height }\end{array}$ & $\begin{array}{l}2860 \\
5810 \\
1600 \\
\end{array}$ & $\begin{array}{l}3170 \\
6050 \\
1680 \\
\end{array}$ & $\begin{array}{l}3440 \\
5840 \\
1860 \\
\end{array}$ & \begin{tabular}{|l|}
2860 \\
5820 \\
1770 \\
\end{tabular} & $\begin{array}{l}3250 \\
6000 \\
1600 \\
\end{array}$ & \begin{tabular}{|l}
$2300 \times$ \\
$5800 \times$ \\
1600 \\
\end{tabular} \\
\hline $\begin{array}{l}\text { Range of working height } \\
\text { authorities cut, cm }\end{array}$ & $\begin{array}{l}\text { from } 40 \text { to } \\
180 \\
\end{array}$ & \begin{tabular}{|l|} 
from 50 to \\
120 \\
\end{tabular} & no data & \begin{tabular}{|l|} 
from 40 to \\
180 \\
\end{tabular} & $\begin{array}{l}\text { from } 50 \text { to } \\
120\end{array}$ & \begin{tabular}{|l} 
from 40 to \\
180 \\
\end{tabular} \\
\hline Total weight, $\mathrm{kg}$ & 1900 & 2010 & 2830 & 1770 & 1910 & 1900 \\
\hline
\end{tabular}

Table 3. Technical characteristics of devices for harvesting sunflower with the number of rows to be removed twelve

\begin{tabular}{|l|l|l|}
\hline Name of indicator & \multicolumn{2}{|c|}{ Value of parameter } \\
\hline Device brand & $\begin{array}{l}\text { PSP-1210-35 } \\
\text { «FALCON» }\end{array}$ & ZHNS-9,1 \\
\hline Structural width, $\mathrm{m}$ & 8,4 & 9,2 \\
\hline $\begin{array}{l}\text { Driving speed, } \mathrm{km} / \mathrm{h}: \\
\text { - working } \\
\text { - transport }\end{array}$ & $\begin{array}{l}7,0-9,0 \\
\text { up to } 12,0\end{array}$ & $\begin{array}{l}9,5 \\
\text { Motor vehicles }\end{array}$ \\
\hline $\begin{array}{l}\text { Overall dimensions, } \mathrm{mm}: \\
\text { - length }\end{array}$ & 2840 & 2350 \\
- width & 8570 & 9450 \\
- height & 1590 & 1100 \\
\hline Range of working height authorities cut, $\mathrm{cm}$ & from 40 up to 180 & Not available \\
\hline Total weight, kg & 3200 & 3050 \\
\hline
\end{tabular}

Tests of devices are carried out on typical backgrounds in zones of activity of farms and the corresponding MIS (Table 4). Devices for sunflower harvesting meet the requirements of regulatory documents on the indicators of purpose and safety, as well as meet the modern requirements of agricultural production. Some noted inconsistencies in some products do not require significant changes in the design of devices and can be eliminated during the production of these machines.

Harvesting was carried out by combine harvesters at a working speed of 3,8 to $9,6 \mathrm{~km} / \mathrm{h}$. the Average height of the cut of plants on the tested devices was $62,0 \mathrm{~cm}$. At the same time, the lowest cut height was at the device OptiSun-870-PSM - 17,6cm. In this embodiment, the harvesting unit is equipped with a device equipped with a chopper of stems, which is able to grind the ground part of plants as low as possible with scattering it over the entire width of the capture. Given that after harvesting requires high energy intensity and difficulty in preparing the soil for sowing winter crops, the presence of the device OptiSun870-PSM chopper stems can reduce and partially remove this problem [4]. 
Table 4. Test conditions and functional parameters of sunflower harvesting devices

\begin{tabular}{|c|c|c|c|c|c|c|c|c|}
\hline $\begin{array}{l}\text { Name of } \\
\text { indicator }\end{array}$ & \multicolumn{8}{|c|}{ Value of parameter } \\
\hline \multicolumn{9}{|c|}{ Test conditions } \\
\hline $\begin{array}{l}\text { Aggregation } \\
\text { with } \\
\text { combine/Device } \\
\text { brand* } \\
\end{array}$ & 1 & 2 & 3 & 4 & 5 & 6 & 7 & 8 \\
\hline $\begin{array}{l}\text { Yield when the } \\
\text { actual humidity } \\
\text { content, } \mathrm{kg} / \mathrm{ha}\end{array}$ & 10,9 & 10,5 & 24,7 & 17,2 & 10,8 & 39,3 & 31,7 & 28,6 \\
\hline $\begin{array}{l}\text { Humidity, \%: } \\
\text { - grains } \\
\text { - non-grain part }\end{array}$ & $\begin{array}{l}11,8 \\
41,1\end{array}$ & $\begin{array}{l}17,6 \\
52,1\end{array}$ & $\begin{array}{l}8,8 \\
16,5\end{array}$ & $\begin{array}{l}6,1 \\
18,2\end{array}$ & $\begin{array}{l}9,5 \\
10,7- \\
19,6\end{array}$ & $\begin{array}{l}3,5 \\
24,8\end{array}$ & $\begin{array}{l}4,3 \\
38,0\end{array}$ & $\begin{array}{l}7,0 \\
38,9\end{array}$ \\
\hline \multicolumn{9}{|c|}{ Operational and technological parameters } \\
\hline $\begin{array}{l}\text { Operating speed, } \\
\mathrm{km} / \mathrm{h}\end{array}$ & 7,7 & 7,7 & 9,6 & 9,5 & 9,0 & 3,8 & 5,2 & 5,5 \\
\hline $\begin{array}{l}\text { Width of capture, } \\
\mathrm{m}\end{array}$ & 8,4 & 5,6 & 5,6 & 9,2 & 5,6 & 5,6 & 5,6 & 5,6 \\
\hline $\begin{array}{l}\text { Productivity for } 1 \\
\text { hour of time, ha } \\
\text { (t): } \\
\text { - main } \\
\text { - removable }\end{array}$ & $\begin{array}{l} \\
6,5(6,9) \\
4,3(4,6)\end{array}$ & $\begin{array}{l}4,3(4,5) \\
3,3(3,4)\end{array}$ & $\begin{array}{l}5,4(13,4) \\
3,7(9,2)\end{array}$ & $\begin{array}{l}8,6(14,9) \\
5,4(9,4)\end{array}$ & $\begin{array}{l}5,0(5,4) \\
3,4(3,7)\end{array}$ & $\begin{array}{l}2,1(8,2) \\
1,5(5,9)\end{array}$ & $\begin{array}{l}2,9(9,2) \\
2,2(6,9)\end{array}$ & $\begin{array}{l}3,0(7,2) \\
2,2(5,1)\end{array}$ \\
\hline $\begin{array}{l}\text { Specific fuel } \\
\text { consumption } \\
\text { during shift } \\
\text { operation, kg/ha } \\
(\mathrm{kg} / \mathrm{t})\end{array}$ & $9,4(8,6)$ & $5,6(5,3)$ & $5,8(2,4)$ & $2,6(1,5)$ & $9,3(8,6)$ & $27,7(7,0)$ & $8,8(2,8)$ & $9,6(4,1)$ \\
\hline $\begin{array}{l}\text { Operational and } \\
\text { technological } \\
\text { factors: } \\
\text { - process } \\
\text { reliability } \\
\text { - use of } \\
\text { changeable time }\end{array}$ & $\begin{array}{l}0,89 \\
0,66\end{array}$ & $\begin{array}{l}1,0 \\
0,76\end{array}$ & $\begin{array}{l}1,0 \\
0,68\end{array}$ & $\begin{array}{l}0,99 \\
0,63\end{array}$ & $\begin{array}{l}1,0 \\
0,68\end{array}$ & $\begin{array}{l}1,0 \\
0,73\end{array}$ & $\begin{array}{l}1,0 \\
0,75\end{array}$ & $\begin{array}{l}1,0 \\
0,71\end{array}$ \\
\hline \multicolumn{9}{|c|}{ Quality of the process } \\
\hline Cut height, cm & 52,0 & 50,2 & 59,0 & 79,4 & 40,0 & 17,6 & 87,0 & $\begin{array}{l}\text { Not } \\
\text { available }\end{array}$ \\
\hline $\begin{array}{l}\text { Grain losses, \%: } \\
\text { - everything, } \\
\text { including: } \\
\text { - behind the } \\
\text { device }\end{array}$ & $\begin{array}{l}1,7 \\
0,2\end{array}$ & $\begin{array}{l}1,9 \\
0,9\end{array}$ & $\begin{array}{l}1,4 \\
0,9\end{array}$ & $\begin{array}{l}2,3 \\
0,5\end{array}$ & $\begin{array}{l}2,4 \\
1,6\end{array}$ & $\begin{array}{l}\text { Not } \\
\text { available } \\
0,5\end{array}$ & $\begin{array}{l}\text { Not } \\
\text { available } \\
0,9\end{array}$ & $\begin{array}{l}1,8 \\
0,9\end{array}$ \\
\hline
\end{tabular}

* Aggregation with combine/Device brand: 1 - RSM -161/PSP-1210-35 «FALCON, 2 RSM-142 "ACROS 580»/ PSP-810-05 «FALCON», 3 - GS 12 «PALESSE»/ NASH-87304, 4 - RSM -181 «TORUM 740»/ZHNS-9,1, 5 - RSM -181 «TORUM 740»/ PSP-810-13, 6 - Challenger 660/ OptiSun-870-PSMЮ, 7 - RSM-142 "ACROS 530»/PSP-810, 8 - John Deere 9670 STS/ NASH-873-06

An indicator of the quality of the devices is the level of grain loss. All tested devices had indicators on the level of grain losses that meet the agrotechnical requirements (not more than $2,0 \%$ ) and were in the range from $0,2 \%$ to $1,6 \%$. The best indicators among them 
were adaptations of PSP-1210-35 "FALCON" brands (0,2\%), OptiSun-870-PSM (0,5\%) and sunflower ZHNS-9,1 (0,5\%) in which the loss rate did not exceed 0,5\%.

The tested devices had a different width and number of rows to be removed. 8-row devices brands PSP-810-05 "FALCON", NASH-873-04, PSP-810-13, OptiSun-870-PSM, PSP-810, NASH-873-06 had a width of 5,6m. Wide-12-row device PSP-1210-35 "FALCON" width 8,4m and header brand ZHNS-9,1 with a width of 9,2m.

Interchangeable combine harvester with 8-row devices ranged from 1,5ha/h at OptiSun870-PSM to 3,7ha/h in NASH-873-04. Have a wide fit and the reapers it was a $4,3 \mathrm{ha} / \mathrm{h}$ from PSP-1210-35 "FALCON" and 5,4ha/h at ZHNS-9,1. Low removable capacity for the unit Challenger $660+$ OptiSun-870-PSM $(1,5 \mathrm{ha} / \mathrm{h})$ is obtained due to the low operating speed $(3,8 \mathrm{~km} / \mathrm{h})$ in comparison with other units due to the work of the chopper stems with a cut height of $17,6 \mathrm{~cm}$, which requires a certain amount of power for the technological process of cleaning. In connection with the energy-intensive process of grinding the stems, this unit also had an increased fuel consumption by $26,3 \%$ compared to other units.

Fuel consumption of the tested units was in the range from 5,6 to $9,6 \mathrm{~kg} / \mathrm{ha}$. Low fuel consumption provided the unit TORUM $740+$ ZHNS-9, $1(2,6 \mathrm{~kg} / \mathrm{ha})$, which is primarily due to the fact that the design of the header is no chopper stems, and the collection of baskets is carried out by lifters at a cut height of $80,0 \mathrm{~cm}$.

The results of the tests indicate that the most acceptable for sunflower harvesting are adaptations of brands: PSP-810-05 "FALCON", NASH-873-04, OptiSun-870-PSM, PSP810, NASH-873-06, PSP-1210-35 "FALCON" and ZHNS-9,1 in the unit with combine harvesters. They provide the best indicators on the level of grain losses up to $0,9 \%$, satisfying agricultural requirements (not more than 2,0\%). Similar results were obtained as a result, of previous research work adaptations for sunflower cleaning specialists KubNIITiM in economic conditions [5]. From the results of the researches of the specialists of KubNIITiM also follows that the best performance in terms of grain losses, meet the agronomic requirements (not more than 2,0\%), provided the 8-row fixture PSP-810 and NASH- $873-0,4 \%$ in the unit with harvesters ACROS 580 and Palesse GS 12 respectively.

\section{Conclusion}

Adaptations to combine harvesters are able to fully meet the needs of the combine fleet of farmers in the harvesting of sunflower, meet the indicators of destination, reliably and efficiently perform the technological process. Most of the tested devices for sunflower harvesting are produced at domestic agricultural machine-building plants. Some samples are purchased in foreign countries (Hungary). At the same time, imported devices do not have significant functional advantages over domestic ones. The presence of devices of these brands in the harvest park farms indicates the high technical level of domestic manufacturers (JSC "Morozovskselmash", town of Morozovsk and Ltd. joint venture "Unisibmash", Novosibirsk).

\section{References}

1. M.E. Chaplygin, Machinery and equipment for the village, 11, pp. 16-19. (2016)

2. V.F Fedorenko etc., Scientific basis for the production of high-quality wheat. (Moscow: VIM, 2018)

3. S.A Davydova, O.N Bespalova, V.N. Rudenko, M.E. Chapligin, Innovative projects in agricultural engineering. (Astrakhan, 2017)

4. V.I. Skornyakov, M.E. Chapligin, Agrosnabforum, 6, pp. 56-58 (2014). 
5. M.E. Chapligin, E.V. Bondarenko, M.A. Belik, Agribusiness, 6, pp. 82-84. (2014) 